\title{
PRINSIP KEMASHALAHATAN UMAT DAN PENGHARGAAN TERHADAP HUKUM DALAM BINGKAI KESADARAN MULTIKULTUR KEHIDUPAN BERAGAMA DI INDONESIA
}

\author{
Oleh: Iskandar ${ }^{1}$
}

\begin{abstract}
Indonesia is a country inhabited by various tribes, races and religions. A long history of Indonesian nation with various ethnics make kind of multicultural religious which is brought lives phenomenon. Islam as the majority religion in Indonesia provides significant meaning in appreciating benefit and respecting the diversity religious of people in Indonesia. The concept of rahmatan lil Alamin is seeded according to the context in Indonesia. Thus, an inclusive understanding by collocated Islam as a progressive religion nowadays becomes a necessity to solve problems and the importance of a complex buman beneficial. On the other hand, the necessity of multicultural awarenness of religious in Indonesia made this country as barometer of other country in appreciating a fair law to all the citizens, but when the diversity of this nation does not respect other religions, it will bother the religious' stability and national life in the country. Islam has given point of views in national life and tanght how to respect other people who bas different belief. So, people who has different belief should do the same to appreciate Islam. The history of the world has taught us about the importance of appreciate people and respect the law for the nation, then the nation will be a peaceful and prosperous country.
\end{abstract}

Keywords: Beneficial, Appreciation, a Multicultural

\section{A. Pendahuluan}

Meletakkan Islam sebagai ajaran rahmat menjadi "pintu" memahami Islam secara tekstual dan kontekstual sekaligus secara sempurna (kafah). Pemahaman Islam kemudian melahirkan polarisasi, yakni dipahami eksklusif dan inklusif-progresif. Ekslusivisme beragama yang dibangun atas doktrin-doktrin teologis dengan mengonsumsi teks yang membuahkan pemahaman tekstual-literal menjadikan Islam dipahami sempit.

Sementara Islam sebagai agama progresif sesuai dengan misinya sebagai rabmatan lil alamin, sejatinya teks disemaikan sesuai dengan konteks. Maka, pemahaman yang inklusif dengan menempatkan Islam sebagai agama progresif menjadi keharusan dengan membedah problem dan kepentingan (maslahat)

${ }^{1}$ Dosen Jurusan Syariah dan Ekonomi Islam STAIN Syaikh Abdurahman Siddik Bangka Belitung, email: iskandarmhum@gmail.com 
kemanusiaan yang kian kompleks.

Islam yang mengalami proses historisitas sepanjang sejarah perjalanan umat Islam melahirkan beragam tafsir melalui pergulatan teologis yang sarat dengan doktrin, hal yang sama juga berimbas pada aspek fikih, politik, dan tasawuf. Proses tersebut kemudian menumbuhkan kesadaran intelektual muslim dalam menafsirkan Islam sebagai agama progresif yang rahmatan lil alamin dengan memposisikan agama sebagai rahmat tersebut. Agenda membumikan Islam sesuai dengan konteks zaman, di mana Islam selalu dihadirkan (ditafsirkan, disesuaikan) untuk memberi solusi atas problem-problem atau maslahat (kepentingan) kemanusiaan.

Sebuah pemikiran filosof Yunani Epicurus ${ }^{2}$ mengatakan bahwa maslahah itu bersifat relatif dan subjektif, tergantung individu seseorang, tanpa memandang dampak yang ditimbulkan. Pola pikir seperti ini berpengaruh kuat pada masyarakat Eropa, sehingga melahirkan ide-ide seperti: HAM, persamaan hak, dan lain-lain. Mereka berasumsi bahwa akal manusia tidak perlu lagi sesuatu yang lain (agama) dalam menentukan maslahah. ${ }^{3}$

Namun hal tersebut sebagai pandangan dalam paradigma diluar Islam. Menurut istilah secara umum Maslahah dimaknakan dengan mendatangkan segala bentuk kemanfaatan atau menolak segala kemungkinan yang merusak. sedangkanmanfaat adalah ungkapan dari sebuah kenikmatan atau segala hal yang masih berhubungan denganya, kerusakan adalah hal-hal yang menyakitkan atau segala sesuatu yang ada kaitan dengannya. Secara bahasa, maslahah adalah bentuk masdar dari madli sholaha dan bentuk tunggal dari jama' masholeb yang artinya sama dengan manfaat. Oleh karenanya, segala sesuatu yang mempunyai nilai manfaat bisa disebut maslahah. ${ }^{4}$

Maslahah menurut istilah ulama bisa didefinisikan sebagai berikut :

${ }^{2}$ Epicurus (341 SM.-271 M.) filosof Yunani, kemudian pemikiran ini diadopsi oleh filosof modern, seperti Thomas Hobbes (1588-1679 M.)

${ }^{3}$ Lebih lanjut mengenai hal ini dijelaskan oleh filsofot Zenon (270-342) filosof Yunani,ia hidup satu masa dengan Epicurus kemudian teori ini dikembangkan oleh filosof modern termasuk Immanuel Kant (1724-1804 M.)

${ }^{4}$ W.J.S. Poerwadarminta, Kamus Umum Bahasa Indonesia, (Jakarta: 1976), Huruf M,hal. 635 dan lihat juga dalam AmirSyarifuddin,UshulFiqh,(Jakarta:LogosWacanaIlmu,1999),CetI, Jilid II,hal.323 dan lihat juga Abû Ishâq al-Syâtibi, al-Muwâfaqât fi Usûl al-Syarìah, (Beirut: Dâr al-Kutub al-,Ilmiyyah, t.th.), juz I, hlm. 227. 
1. Manfaat yang ditujukan kepada umat manusia oleh syari' untuk menjaga agama, jiwa, akal, keturunan dan harta sesuai ranking.

2. Menurut pengertian al-Rozi, maslahah adalah manfaat yang menghasilkan kenikmatan atau untuk menolak bahaya.

Jika kita lihat uraian di atas, pengertian ini bertentangan dengan pengertian sebagian filosof. Menurut mereka, maslahah adalah sebuah manfaat untuk menuju kenikmatan, atau menolak bahaya di dunia semata. Sebab, segala sesuatu di muka bumi ini baik berupa kebajikan atau kejehatan tergantung pada kesepakatan bersama umat manusia. Karena memandang manusia sebagai subjek yang bisa menentukan standar nilai perbuatan mereka (baik/jelek).

Pandangan terhadap Maslahah tebagi menjadi dua bagian, yaitu pandangan maslahah menurut kaum sosialis materialis serta pandanganya menurut syara' (hakikat syara'), dalam pembahasan pertama al Syatiby mengatakan: “maslahah ditinjau dari segi artinya adalah segala sesuatu yang menguatkan keberlangsungan dan Menyerpurnakan kebidupan manusia, serta memenubi segala keinginan rasio dan syabwatnya secara mutlak.". Sedangkan menurut arti secara Syara' (bakikat) adalah segala sesuatu yang menguatkan kehidupan di dunia tidak dengan cara merusaknya serta mampu menuai hasil dan beruntung di akhirat, dalam hal ini al Syatiby mengatakan, " menarikkemaslabatan dan membuang hal-hal yang merusak bisa juga disebut dengan melaksanakan kehidupan di dunia untuk kehidupan di akbirat". 'sedangkan menurut al Ghozali maslahah adalah: “memelibara tujuan daripada syari'at”. sedangkan tujuan syara' meliputi lima dasar pokok, yaitu: 1.melindungi agama (bifdu al diin), 2.melindungi jiwa (bifdu al nafs), 3.melindungi akal (bifdu al aq), 4.melindungi kelestarian manusia (bifdu al nash), 5.melindungi harta benda (bifdu al mal).

Walaupun para ulama berbeda-beda dalam memandang maslahah mursalah, hakikatnya adalah satu, yaitu setiap manfaat yang didalamnya terdapat tujuan syara

${ }^{5}$ Wahbah Zuhaili,Ilmu Ushl al Figh., juz II.hlm.799-800.

${ }^{6}$ Abd. Wahbah Khalaf,Ilmu ushul figh, hlm. 86.

${ }^{7}$ M.Ibn Ahmad Taqiyah, Masadiru al Tasyri' al Islamy, (Lebanon: muasisu al kitab al tsaqofiyah, 1999),hlm. 138, lihat juga dalam Rachmat Syafe'i, Ilmu Ushul Fiqh, (Bandung, CV Pustaka Setia, 1998) Cet. IV, hal. 117 
secara umum, namun tidak terdapat dalil yang secara khusus menerima atau menolaknya. ${ }^{8}$

Hal yang membedakan antara Qiyas dan Maslahah mursalah adalah Qiyas berangkat dari illat (alasan utama suatu nash) sedangkan maslahah mursalah berangkat dari hikmah. Hikmah adalah perbuatan yang arif yang mempunyai manfaat syari'ah secara sosial. Abdul Wahab Khallaf memberi contoh simpel yang berkaitan dengan keringanan mengqadla shaum ramadhan pada bulan lain jika shafar atau sakit. Kondisi Shafar dan sakit adalah illat sedangkan keringanan dari sebuah kesulitan adalah hikmah. ${ }^{9}$

Dalam mengurai Islam sebagai paradigma kemanusiaan, Islam dihadirkan untuk menyelamatkan (petunjuk) manusia dari berbagai problem kemanusiaan sekaligus menghadirkan Islam sebagai agama kemanusiaan dengan ajaran keadilan, kemaslahatan, pembebasan, persaudaraan, perdamaian dan kasih sayang. Pada aras ini, Islam sebagai agama progresif menemukan relevansinya dengan mempertautkan dalam konteks kekinian.

Kontekstualisasi doktrin Islam progresif yang menyerukan atau menegaskan kembali maslahat, sehingga Islam selalu menjadi ajaran yang relevan dengan konteks kekinian, Islam memiliki kepekaan dengan tradisi, modernitas, dan sejumlah problem kemanusiaan, tidak terkecuali persoalan kemiskinan, nasionalisme, dan terorisme. Serentetan uraian inilah yang menjadi bagian pembahasan wacana Islam progresif sebagai langkah menegaskan kembali pentingnya prinsip maslahat atau kepentingan yang menjadi bagian urgen dalam Islam itu sendiri. Upaya ini merupakan bagian proyek gerakan pemikiran, guna membendung maraknya revitalisme agama yang mengusung diktum-diktum literalistik atau simbolisasi an sich seperti penegakan syariat Islam.

Sejarah dunia, sejak dahulu hingga sekarang, terus diwarnai oleh adeganadegan tragis, antara satu manusia dengan manusia lain. Pembantaian antara Qabil dan Habil, anak kandung Nabi Adam dan Hawa, telah menjadi contoh yang tidak baik pada generasi dan keturunan selanjutnya. Pembantaian satu lawan satu, seperti yang terjadi pada kasus Qabil dan Habil, kini meluas antara kelompok, suku, etnik,

\footnotetext{
${ }^{8}$ Rachmat Syafe'i, Ilmu Ushul Figh, (Bandung, CV Pustaka Setia, 1998) Cet. IV, hal. 119

${ }^{9}$ Ibid, hal. 128
} 
agama, ras dan kepentingan lainnya. Zaman Nazi dan Hitler, orang menganggapnya sebagai pembantaian paling sadis dalam sejarah peradaban dunia. Tetapi ternyata, pembantaian susulannya pun tidak kalah sadis. Contohnya adalah pembantaian tersadis di Bosnia Herzegovina, Kosovo, Tiaananmen, Macan Tamil, Afghanistan, hingga kejadianyang terus meluas sampai ke Indonesia.

Di Indonesia sendiri tercatat peristiwa pembantaian sadis itu sejak tahun 1948 peristiwa Madiun, menyusul 1965 G.30 S/PKI, Tanjung Priok, Poso, Sampit, Ambon, dan juga di ibukota, Jakarta. Al-Qur'an teramat serius mengajarkan kepada umat manusia tentang paham kemajemukan keagamaan (religious plurality). Paham itu berintikan pesan moral bahwa kaum Muslimin, kaum Yahudi, kaum Nasrani dan kaum Sabi'an, atau siapa saja yang beriman kepada Allah hari kemudian serta berbuat kebaikan (amal saleh), maka mereka akan menerima balasan (pahala) dari Tuhan mereka.

Bahkan, mereka dijanjikan tidak akan tertimpa perasaan khawatir, dan mereka pun dijamin tidak akan bersedih hati. Ajaran al-Qur'an itu tidaklah perlu diartikan sebagai pengakuan akan kebenaran semua agama dalam bentuk praktik nyata seharihari. Sebab, dalam praktik nyata keagamaan sehari-hari, kaum muslimin pun sebenarnya banyak sekali melakukan kesalahan-kesalahan dalam menjalankan ajaran agamanya, seperti sikap memitoskan tokoh atau makhluk lain baik yang masih hidup maupun yang sudah mati. Agama menyebutnya sebagai perbuatan syirik atau menyerikatkan Allah.

Karena itu, prinsip ajaran ini menandaskan bahwa kebenaran hakiki dalam beragama adalah "percaya" (tauhid) hanya kepada Allah SWT. Kelanjutan logisnya, semua agama diberikan kebebasan untuk hidup, dengan resiko bahwa pilihan paham keagamaannya itu akan ditanggung sendiri-sendiri oleh para pengikut agama masingmasing, baik secara pribadi maupun secara kelompok, bila di kemudian hari ternyata dia menganut agama secara salah. Karenanya, kita semua dianjurkan oleh agama masing-masing untuk saling mengakui dan menghormati, bukan saling menghakimi dan menghancurkan. Sebab, kendati pilihan jalan hidup kita berbeda-beda, namun pada hakekatnya, Tuhan yang kita puji adalah Tuhan yang satu, yaitu Allah.

Abad ini, rupanya abad kekacauan agama-agama: suatu abad yang paling banyak menyuguhkan tragedi kemanusiaan daripada mengembangkan tradisi 
keagamaan. Banyak orang meratap dalam penyesalan, bahwa agama yang selalu mendambakan keselamatan hidup itu, di tangan pemeluknya, ternyata dijadikan "alat penindasan" untuk saling menyengsarakan, agama yang selalu menawarkan keharmonisan hidup itu, di pundak penganutnya ternyata ia dijadikan "instrument ideology "untuk saling menyingkirkan. Bukankah akhir-akhir ini di hampir sebagian besar belahan dunia telah tumbuh pesat apa yang disebut orang sebagai "dendam sosial" atas nama agama dan suku bangsa.

Secara perlahan, kata psikolog Austria, Sigmund Freud (1856-1939), kekuatan jahat yang merindukan (dan rasa takut terhadap) permusuhan, muncul dalam peradaban modern. Orang-orang mulai khawatir terhadap peradaban yang mereka ciptakan sendiri. Kendati demikian, mereka juga menikmati keuntungan yang diberikan oleh peradaban modern itu. Berkat ilmu pengetahuan modern, sebagian besar masyarakat abad ini menikmati hidup dalam tingkat kesehatan yang lebih baik dan usia harapan hidup yang lebih panjang. Namun, impian akan persaudaraan universal yang menjadi sumber eksistensi para pemikir pencerahan, hingga saat ini belum menuai kenyataan. ${ }^{10}$

Freud dalam kata-kata terakhirnya itu boleh jadi kecewa dalam kenyataan pahit yang diderita umat manusia. Kenyataan bahwa di satu sisi umat manusia menggegam agama sebagai pijakan moral untuk menumbuhkan cinta persaudaraan universal, toh pada kenyataannya mereka justru lebih sibuk saling menyerang dan melenyapkan daripada menjalin persaudaraan hakiki; sementara di sisi lain umat manusia di abad ini mengusung ilmu pengetahuan dan teknologi sebagai kekuatan utama peradaban modern untuk memfasilitasi kehidupan bersama, toh, dalam perkembangannya justru lebih sering dijadikan sebagai 'tongkat pemukul' antara kelompok manusia dengan kelompok manusia lainnya daripada mensejahterakan kehidupan bersama.

Kontekstualisasi pemahaman Islam yang progresif dengan mengedepankan nilai-nilai kemanusiaan universal itu, tentu hanya akan tergapai dengan keberanian melakukan dekonstruksi tradisi, yakni pada tradisi yang menjumudkan umat. Menjadi suatu kelaziman jika dilakukan penelusuran di atas hamparan bentangan sejarah Islam

10 George Boeree, Personality Theories; Melacak Kepribadian Anda Bersama Psikologi Dunia, (Yogyakarta:PrismaSophie, 2005), hlm 85. 
sebagai bagian pemikiran Islam adalah mengenai tradisi (turats).

Mengurai problem Islam dan maslahat kemanusiaan dengan berbagai dinamikanya selalu terhadang pada problem penafsiran yang literal. Hal demikian membatasi ruang gerak umat beragama yang terjebak pada simbol ritualistik.

Sementara Islam hadir sebagai agama pembebasan atas problem kemanusiaan dalam seluruh lini kehidupannya. Hal ini tetap menjadi problem selama tafsir literal belum mewujud sebagai tafsir kontekstual yang peka pada realitas sosial. Dimensi sosial ini justru terabaikan dengan bias pemahaman dan pengamalan atas tradisi secara privat.

Dalam konteks inilah, tradisi atau turats ini perlu dibaca ulang, tepatnya mendekonstruksi tradisi. Tradisi merupakan pedoman dan peranti dalam membentuk masyarakat selama ini disempitkan dengan memahami teks sesuai dengan kepentingan ideologis-teologis yang sempit.

Implikasinya, tradisi menjadi "kitab suci" yang harus dipedomani dalam perilaku kehidupan sehari-hari. Sebab itu, tradisi menjadi problematika yang cukup fenomenal dan signifikan. Dalam hal ini, tradisi bermetamorfosis menjadi tradisionalisme. Tradisi yang dipelintir dan direkayasa dengan penafsiran literal menjadikan teks suci sekalipun menjadi ternoda dalam eksklusivisme dan mengungkung kreativitas keagamaan.

Di satu sisi, tradisi merupakan khazanah pemikiran yang bersifat material dan immaterial, sejatinya harus dikembangkan untuk melahirkan pemikiran progresiftransformatif. Namun, di sisi lain tradisi menjadi ancaman dan hambatan dalam mewujudkan perubahan di tengah-tengah masyarakat. Indikasinya, muncul gerakangerakan yang ingin merevitalisasi tradisi. Kecenderungan kembali ke tradisi cukup besar, sehingga tidak heran apabila buku-buku klasik mengalami revisi untuk dijadikan rujukan utama dalam memahami persoalan modernitas secara gegabah.

Fenomena ini sebagai pemahaman tradisionalistik terhadap tradisi. Mereka meyakini dalam memecahkan persoalan kekinian dan mencari jalan keluar dari kubangan kesengsaraan, sepertinya tidak ada jalan lain selain kembali dan merujuk pada tradisi. Misalnya, dalam mengantisipasi degradasi moral dan kesemrawutan politik, solusi yang diajukan adalah dengan menerbitkan buku-buku mengenai keutamaan sahabat (fadlail al-sababah) atau tentang keutamaan para ahli surga. 
Tampaknya metodologi berpikir yang demikian kurang relevan dengan konteks kalau itu ditujukan membendung dekadensi moral. Tetapi, yang riil adalah dengan memahami realitas atau konteks seiring proses transformasi sosial.

Tampaknya pemikiran-pemikiran yang demikian yang perlu didekonstruksi dengan menawarkan doktrin pemikiran-pemikiran progresif. Bagian pemikiran progresif ini adalah membendung tradisionalisme yang justru ditengarai melahirkan ekses seperti hipokritas, ketertindasan atau keterpurukan, dan narsisme.

Tetapi, tradisi tidak bisa ditinggalkan tetapi perlu dikontekstualisasi secara arif dengan zaman sebagai solusi atas kemaslahatan umat secara universal. Untuk lebih riil, perlu melampaui tradisi dengan mendedah pemikiran-pemikiran progresif. Jika demikian halnya, dekonstruksi tradisi menjadi keniscayaan guna melahirkan pemahaman keagamaan yang kontekstual selaras dengan napas Islam yang memiliki kepekaaan atas realitas sosial dan kemanusiaan universal.

\section{B. Pembahasan}

\section{Fungsi Hukum Sebagai Instrumen Perlindungan}

Salah satu fungsi dari hukum ialah sebagai alat untuk melindungi kepentingan manusia atau sebagai perlindungan kepentingan manusia. Upaya yang semestinya dilakukan guna melindungi kepentingan manusia ialah hukum harus dilaksanakan secara layak. Pelaksanaan hukum dapat berlangsung secara damai, normal tetapi dapat terjadi pula karena pelanggaran hukum. Dalam hal ini hukum yang telah dilanggar tersebut haruslah ditegakkan, dan diharapkan dalam penegakan hukum inilah hukum tersebut menjadikan kenyataan.

Dalam hal penegakan hukum tersebut, setiap orang selalu mengharapkan dapat ditetapkannya hukum dalam hal terjadinya peristiwa kongkrit, dengan kata lain bahwa peristiwa tersebut tidak boleh menyimpang dan harus ditetapkan sesuai dengan hukum yang ada (berlaku), yang pada akhirnya nanti kepastian hukum dapat diwujudkan. Namun perlu diingat bahwa dalam penegakan hukum ada tiga unsur yang selalu harus diperhatikan guna mewujudkan hakikat dari fungsi dan tujuan itu sendiri, yaitu: kepastian hukum (rechtssicherbeit), kemanfaatan (zweckmassigkeit) dan keadilan (gerechtgkeit). Tanpa kepastian hukum orang tidak mengetahui apa yang harus diperbuat yang pada akhirnya akan menimbulkan keresahan. 
Akan tetapi terlalu menitik beratkan pada kepastian hukum, terlalu ketat mentaati peraturan hukum akibatnya jug akan kaku serta tidak menutup kemungkinan akan dapat menimbulkan rasa ketidak adilan. Apapun yang terjadi peraturannya adalah demikian dan harus ditaati dan dilaksanakan. Dan kadang undang-undang itu sering terasa kejam apabila dilaksanakan secara ketat (lex dura sed tamen scripta).Berbicara tentang hukum pada umumnya, kita (masyarakat) hanya melihat kepada peraturan hukum dalam arti kaedah atau peraturan perundangundangan, terutama bagi para praktisi. ${ }^{11}$

Sedang kita sadar bahwa undang-undang itu tidaklah sempurna, undangundang tidaklah mungkin dapat mengatur segala kegiatan kehidupan manusia secara tuntas. Ada kalanya undang-undang itu tidak lengkap atau ada kalanya undangundang tersebut tidak jelas. Tidak hanya itu, dalam Al-Qur'an sendiri yang merupakan rujukan kita (umat Islam) dalam menentukan hukum akan suatu peristiwa yang terjadi, ada kalanya masih memerlukan suatu penafsiran (interpretasi), pada masalah-masalah yang dianggap kurang jelas dan dimungkinkan (terbuka) atasnya untuk dilakukan suatu penafsiran. Dalam hal terjadinya pelanggaran undang-undang, penegak hukum (hakim) harus melaksanakan atau menegakkan undang-undang.

Hakim tidak dapat dan tidak boleh menangguhkan atau menolak menjatuhkan putusan dengan alasan karena hukumnya tidak lengkap atau tidak jelas. Hakim dilarang menolak menjatuhkan putusan dengan dalih tidak sempurnanya undang-undang. Olehnya, karena undang-undang yang mengatur akan peristiwa kongkrit tidak lengkap ataupun tidak jelas, maka dalam hal ini penegak hukum (hakim) haruslah mencari, menggali dan mengkaji hukumnya, hakim harus menemukan hukumnya dengan jalan melakukan penemuan hukum (rechtsvinding). ${ }^{12}$

Secara eksplisit, hukum yang kemudian bertujuan pada keadilan adalah manifestasi dari keinginan Tuhan. Kaitannya dengan hal ini, manusia melakukan penemuan hukum yang lazimnya diartikan sebagai proses pembentukan hukum oleh hakim atau petugas-petugas hukum lainnya yang diberi tugas melaksanakan hukum terhadap peristiwa hukum yang kongkrit.

${ }^{11}$ Budiono Kusumohamidjojo, Ketertiban Yang Adil; Problematik Filsafat Hukum,(Jakarta: PT Gramedia Widiasarana Indonesia, 1999), hlm 126.

${ }^{12}$ Ibid 
Hal ini merupakan proses kongkretisasi dan individualisasi peraturan hukum yang bersifat umum dengan mengingat peristiwa kongkrit. Sementara orang lebih suka menggunakan istilah "pembentukan hukum" dari pada "penemuan hukum" oleh karena istilah penemuan hukum memberi sugesti seakan-akan hukumnya sudah ada. ${ }^{13}$

\section{Konsep Multikulturalisme Dalam Konteks Pluralisme Agama}

Islam adalah agama yang di bawa oleh Nabi Muhammad Saw., sejak abad ke VI di Makkah, di tengah-tengah bangsa yang berfaham politeisme yang dikenal dengan sebutan kaum jahiliyyah. Mereka terbiasa hidup bebas tanpa aturan sehingga kedatangan agama Islam sangat menggelisahkan kehidupan mereka. Berbagai gangguan dan ancaman mereka lakukan, antara lain dengan pemboikotan sosial dan ekonomi serta teror fisik dan mental. Semua itu dihadapi Nabi dengan penuh ketabahan hati, sampai kemudian pada puncaknya Nabi beserta para pengikutnya menerima tawaran hijrah ke Yatsrib (Madinah). Pada waktu itu penduduk Madinah sangat beragam dalam kesukuan, budaya dan agama sehingga kehadiran umat Islam menambah khazanah komunitas keagamaan yang telah ada yaitu yahudi, nasrani dam agama-agama suku.

Dalam sejarah Islam dijelaskan bahwa kehidupan umat beragama di Madinah sangat harmonis, antar pemeluk agama saling menghargai dan saling menghormati. Kebebasan dan jaminan menjalankan agama sesuai dengan keyakinan dan kepercayaannya betul-betul terwujud. Semua pemeluk agama sama-sama menjunjung tinggi nilai-nilai luhur yang tertuang dalam Mitsaq al-madinah (Piagam Madinah). Dimana salah satu butir dari piagam madinah tersebut adalah hubungan intern anggota komunitas Islam dan antara mereka dengan komunitas yang lain di dasarkan atas prinsip-prinsip :

a. bertetangga yang baik;

b. saling membantu dalam menghadapi musuh bersama;

c. membela mereka yang teraniaya;

d. saling menasehati dan menghormati kebebasan beragama.

${ }^{13}$ Jean Jacques Rousseau, Du Contract Sosial (Perjanjian Sosial), terjmahan, (Jakarta:Visimedia, 2007), hlm. 60 
Pluralisme diberi makna sebagai doktrin, bahwa substansi hakiki itu tidak satu (monisme), tidak dua (dualisme), akan tetapi banyak (jamak). Pluralisme dapat dipahami sebagai: ${ }^{14}$

a. Suatu teori yang menentang kekuasaan negara monolistis; dan sebaliknya, mendukung desentralisasi dan otonomi untuk semua unsur utama yang mewakili individu dalam masyarakat. Juga suatu keyakinan bahwa kekuasaan itu harus dibagi bersama-sama oleh setiap kelompok.

b. Keberadaan atau toleransi keragaman etnik atau kelompok-kelompok kultural dalam suatu masyarakat dan negara, serta keragaman kepercayaan atau sikap dalam suatu badan, kelembagaan dan lainnya harus terakomodasi dalam dinamika sosial. Karena manusia diciptakan Tuhan untuk saling berinteraksi satu dengan lainnya, termasuk dalam umat berbeda pandangan dan bahkan berbeda agama.

Mengenai pluralisme dalam tradisi Islam, yang dimaksud menunjuk kepada wahyu agama Ibrahimi termuda ini sebenarnya bisa mengungkapkan diri dalam suatu dunia agama pluralistis. Islam mengakui dan menilainya secara kritis, tapi tidak penuh menolaknya atau menganggapnya salah. Malah, ruang spiritual al-Qur,an sebagaimana akan ditunjuk, juga dimiliki agama monoteistik lainnya. Tugas utama yang dimiliki yang dihadapi umat Islam awal adalah melindungi identitas anggotanya dalam pandangan teosentris (berpusat pada Tuhan) yang juga dimiliki oleh tradisi lain. Dengan demikian pluralisme dapat dipahami dan diidentifikasi dengan hal-hal sebagai berikut: ${ }^{15}$

Pertama, selain berkaitan dengan memelihara dan menjunjung tinggi hak dan kewajiban masing-masing kelompok, dalam berbagai bentuk strata sosial, agar dapat berperan sebagaimana yang dapat mereka laksanakan dalam bentuk kewajiban dan bersama sebagai makhluk Tuhan.

Kedua, menghargai perbedaan alam kebersamaan masyarakat yang benar-benar

14 Jeffey Lang, Aku Beriman, Maka Aku Bertanya,Kajian-Kajian Masuk Akal dan Masuk Hati Untuk Meraih Iman Sejati, (Jakarta:Serambi, 2004), hlm. 45.

${ }^{15}$ Ibid 
memiliki karakteristik plural dan meyakini bahwa setiap pihak berada dalam posisi yang sama secarapositif. Mereka meyakini bahwa tidak ada kelompok masyarakat yang lebih unggul dari kelompok lain dalam berbagai hal. Sebagai warga masyarakat yang mempunyai hak, kedudukan dan tanggung jawab yang sama. Perbedaan tidak dipahami sebagai ancaman terhadap eksistensi suatu kelompok.

Ketiga, pluralisme menunjukkan kepada wahana untuk mengembangkan dan meningkatkan kemampuan berkompetisi secara jujur, terbuka dan adil. Karakteristik ini berkaitan dengan upaya menghilangkan pendapat, bahwa dalam kehidupan masyarakat ada kelompok ordinate yang mendominasi kelompok subordinate, kelompok mayoritas merasa lebih unggul dari kelompok minoritas.

Keempat, pluralisme harus didudukan pada posisi yang proporsional. Perbedaan menjadi daya dorong untuk mendinamisasi kehidupan masyarakat, dan bukan mekanisme untuk menghancurkan satu kelompok terhadap kelompok lain. Pluralisme ada pada posisi yang netral, tidak memihak dan obyektif.

Kelima, pluralisme meninjukkan adanya perasaan kepemilikan bersama, untuk kepentingan bersama dan diupayakan bersama. Karakteristik semacam ini pada hakekatnya merupakan puncak dari kesadaran bahwa pluralisme merupakan manifestasi jati diri manusia.

\section{Pandangan Pluralisme Agama}

Bahwa ada tiga prinsip umum dalam merespons keanekaragaman agama. Pertama, logika bersama-Yang Satu yang berwujud banyak. Secara filosofis dan teologis, logika ini merupakan sumber realitas dan cara yang paling signifikan untuk menjelaskan keanekaragaman agama. Bagi mereka yang mendalami sejarah agamaagama, logika ini bukanlah hal yang asing. Misalnya dalam Veda, kita dapat temukan gagasan tentang Yang Satu disebut dengan banyak nama. Dalam agama Budha, hukum karma yang bersifat kausal merupakan realitas. Agama Yahudi dan Kristen memiliki gagasan tentang semua orang dan bangsa di bawah satu Allah dengan berdasarkan pada persepsi al-Kitabiyah. Begitupun dalam Islam, ada gagasan tentang “Asal Kitab" yang merupakan sumber kitab-kitab dari berbagai agama di dunia ini. ${ }^{16}$ 
Kedua, agama sebagai alat. Karenanya wahyu dan doktrin dari agama-agama adalah jalan atau dalam jalan atau dalam tradisi Islam disebut syariat, untuk menuju yang satu. Karena sebagai alat, yang ada dalam agama-agama adalah kumpulan partikular sarana yang digunakan sebagai alat yang dengannya yang satu dapat dicapai. Dari perspektif ini dapat dipahami bahwa bentuk-bentuk agama tidak bisa diperlakukan sebagai kebenaran yang pasti dan mutlak. Dengan demikian, yang dimutlakkan hanya yang satu, bukan bentuk-bentuk dari bermacam-macam agama.

Ketiga, pengenaan kriteria yang mengabsahkan yang dimaksud di sini adalah mengenai kriteria sendiri pada agama-agama lain. Al-Qur'an dalam Islam merupakan wahyu yang mengabsahkan, sehingga menjadi dasar untuk menguji wahyu-wahyu lainnya. Dengan demikian, kriteria yang mengabsahkan ini mutlak adanya bagi agama-agama karena terdapat dalam tradisinya masing- masing guna berlomba-lomba menuju Yang Satu. ${ }^{17}$

Di lain pihak, apa yang dikatakan oleh Farid Esack patut untuk kita renungkangkan bersama. Menurutnya, keunggulan amal saleh bukan berarti posisi superior sosiorelegius yang permanen bagi komunitas muslim. Kaum muslim sebagai sebuah entitas sosial tidaklah superior dibandingkan yang lain, sebab posisi seperti itu akan menempatkan mereka dalam ke dalam kategori yang sama dengan mereka yang dicela dalam Al Qur'an karena kesombongan dan hawa nafsu untuk mengkhususkan Tuhan bagi suatu komunitas yang sempit. ${ }^{18}$

Teguran Al Qur'an pada kaum lain adalah agar mereka tidak mendasarkan klaim superioritas mereka pada prestasi nenek moyang mereka. Seperti disebutkan dalam Surah Al Baqarah ayat 134, yang berbunyi: ${ }^{19}$

"Itu adalah umat yang lalu; baginya apa yang telah diusahakannya dan bagimu apa yang sudah kamu usabakan, dan kamu tidak akan diminta pertanggungan jawab tentang apa yang telah mereka kerjakan"

Umat diartikan sebagai seluruh kelompok manusia yang disatukan oleh sesuatu hal, baik itu agama, masa, maupun tempat. Faktor yang menyatukan mereka

${ }^{18}$ Farid Esack, Membebaskan Yang Tertindas; Al Qur'an, Liberalisme, Pluralisme, Jakarta:Penerbit Mizan, 1997), hlm 223.

${ }^{19}$ Qur'an Karim dan Terjemahan Artinya, UII Press 
adalah takdir atau pilihan manusia sendiri. Bentuk pluralnya adalah umam. Dapat dipahami, Allah menjadikan manusia umat yang satu, kata tersebut berasal dari kata amma-yaummu yang berarti menuju, menjadi, ikatan dan gerakan.

Secara leksikal kata ini mengandung beberapa arti, antara lain: ${ }^{20}$

a. Suatu golongan manusia,

b. Setiap kelompok manusia yang dinisbatkan kepada seorang nabi, seperti umat nabi Nuh AS, umat nabi Ibrahim AS, umat nabi Musa AS, umat nabi Isa AS, dan umat nabi Muhammad SAW.

c. Meskipun mempunyai banyak makna, kata ummah dalam al-Qur'an dapat disimpulkan mengandung pengertian jama'ah, yaitu segolongan manusia yang dipersatukan oleh ikatan sosial sehingga mereka dapat disebut sebagai ummat yang satu demikian pendapat Rasyid Ridha. Al-Qurthubi menyimpulkan penggunaan kata ummah dalam ayat al-Qur'an mengandung pengertian jama'ah atau golongan manusia yang kepada mereka diutus seorang nabi atau rasul. Sementara itu Ali Syariati mengartikan kata ummah dengan jalan yang lurus, yaitu sekelompok manusia yang semua individunya sepakat dalam tujuan yang sama dan masing-masing membantu agar bergerak ke arah tujuan yang diharapkan atas dasar kepemimpinan yang sama.

Jadi dapat dikatakan bahwa:

a. Tuhan tidak menghendaki manusia dalam keadaan yang tunggal atau monolitik;

b. Manusia akan tetap senantiasa berselisih;

c. Yang tidak berselisih ialah mereka yang mendapat rahmat Tuhan;

d. Untuk itulah Tuhan menciptakan manusia;

e. Kebahagiaan dan kesengsaraan abadi bersangkutan dengan masalah perbedaan telah menjadi sunnatullah, maka tidak ada alternatif lain kecuali manusia dapat menerimanya dan menjadi pedoman dalam menjalani kehidupan.

\footnotetext{
${ }^{20}$ Jeffrey Lang, Aku Beriman...., hlm 112.
} 
Dalam penelitian ilmu agama-agama, paling tidak ada tiga sikap keberagamaan: ${ }^{21}$

Pertama, sikap eksklusif. Sikap ini merupakan pandangan yang dominan dari zaman ke zaman, dan terus dianut hingga dewasa ini. Kedua, sikap inklusif. Paradigma ini juga cukup penting dalam menterjemahkan berbagao gejala sosial dewasa ini.

Ketiga, sikap paralelisme. Paradigma ini percaya bahwa setiap agama mempunyai jalan keselamatannya sendiri, dan karena itu klaim kebenaran oleh sekolompok umat beragama harus ditolak, demi alasan-alasan teologis dan fenomenologis. Menurut penganut paham pluralis, misalnya Sayyed Hossein Nasr, menyatakan setiap umat beragama pada dasarnya distruktur oleh dua hal perumusan iman dan pengalaman iman. Hanya saja setiap umat beragama selalu menganggap yang satu selalu mendahului yang kedua. ${ }^{22}$

Persis dalam perbedaan ini, sikap pluralis bisa diterima, karena misalnya antara Islam dan Kristen perbedaannya terletak dalam menaruh mana yang lebih penting antara dua hal tersebut. Islam mendahulukan perumusan iman (tauhid) dan pengalaman iman mengikuti perumusan iman. Dengan demikian dari pendekatan itu saja nampak berbeda pendekatan, sehingga dapat dipastikan merlahirkan hasil yang tampak pula berbeda. Kalau dihayati dengan sungguh-sungguh akan lahir sikap beda antara dua komunitas yang diangkat, perbedaan itu tak harus melahirkan adanya perpecahan dan pertentangan tapi melahirkan saling menghargai dan menghormati.

\section{Penutup}

Tidak seorang pun yang menyangkal bahwa syariat Islam itu dimaksudkan untuk kemaslahatan umat manusia. Syariat itu membawa manusia kepada kebaikan dan kebahagiaan serta mencegah kejahatan dan menolak kebinasaan.

${ }^{21}$ Ratno Lukito, Hukum Islam dan Realitas Sosial, (Yogyakarta:Cakrawala Media, 2008), hlm 156.

22 Taufik Adnan Amal dan Samsu Rizal Panggabean, Politik Syariat Islam; Dari Indonesia Hingga Nigeria,(Jakarta:Pustaka Alvabet, 2004), hlm 113. 
Pokok dan prinsip kemaslahatan itu sudah digariskan dalam teks syariat dengan lengkap dan telah berakhir sejak wafat Nabi Muhammad SAW. Alat dan cara untuk memperoleh kemaslahatan itu berkembang dan beraneka ragam seirama dengan perkembangan sejarah dan peradaban manusia itu sendiri. Kemaslahatan hidup manusia yang ada hubungannya dengan situasi dan kondisi di zaman Nabi, langsung mendapat pengakuan dan pengesahan dari teks syar'i kalau itu dibenarkan, dan dibatalkan kalau tidak dibenarkan. Maslahah yang dibatalkan berarti tidak dianggap sebagai maslahat oleh syariah.

Yang menjadi masalah adalah kemaslahatan yang dirasakan atau dialami orang setelah Nabi wafat, sedangkan teks syariat tidak pernah menyinggung masalah yang seperti itu. Inilah lapangan penggunaan maslahah mursalah yaitu kemaslahatan hidup manusia menurut yang dialami dan dirasakan oleh manusia itu sendiri yang tidak dapat diqiyaskan pada maslahat yang pernah dibenarkan atau dibatalkan oleh teks syariat (nash).

Berdasarkan uraian di atas, maka dapat disimpulkan hal-hal sebagai berikut :

1. Perbedaan adalah sesuatu yang alami, berdasarkan kenyataan alam bahwa banyak sekali bahkan tak terhitung etnis, budaya, kultur, pemikiran dan paham agama.

2. Perbedaan tidak boleh disikapi dengan tindak kekerasan. Dalam hal ini, konteks hukum demi kemashalahan umat menjadi sebuah syarat utama untuk membentuk negara yang damai dan sejahtera seperti yang dicitacitakan Nabi Muhammad SAW.

3. Konsep pluralisme agama tidak boleh disikapi secara emosional. Pluralisme agama dimaksudkan semata-mata agar umat manusia saling hormat-menghormati dalam menjalankan ibadah agamanya.

Agar kehidupan multikultural dapat berjalan dengan baik maka beberapa sikap dalam kehidupan mesti dimiliki, oleh karenanya beberapa hal yang perlusarankan yaitu :

1. Menyikapi perbedaan dengan arif merupakan salah satu syarat masyarakat yang hidup di wilayah Indonesia yang berbasiskan multikultur. 
Prinsip Kemashalahatan Umat Dan Penghargaan Terhadap Hukum ....

2. Dalam menyikapi perbedaan diperlukan sebuah sarana dakwah yang berkiblat pada rasa saling hormat dan menghormati. Dan tidak dibenarkan agama yang satu menghina agama yang lain, karena pemahaman agama yang berbeda.

3. Pemahaman agama tidak boleh dipahami orang lain untuk menghina agama penganutnya. 


\section{DAFTAR PUSTAKA}

Amal, Taufik Adnan dan Samsu Rizal Panggabean, Politik. Syariat Islam; Dari Indonesia Hingga Nigeria, Jakarta: Pustaka Alvabet, 2004

Boeree, George, Personality Theories; Melacak Kepribadian Anda Bersama Psikologi Dunia, Yogyakarta:PrismaSophie, 2005

Esack, Farid, Membebaskan Yang Tertindas; Al Qur'an, Liberalisme, Pluralisme, Jakarta: Penerbit Mizan, 1997

Kusumohamidjojo,Budiono, Ketertiban Yang Adil; Problematik Filsafat Hukum,Jakarta: PT Gramedia Widiasarana Indonesia, 1999

Lang, Jeffey, Aku Beriman, Maka Aku Bertanya,Kajian-Kajian Masuk Akal dan Masuk Hati Untuk Meraib Iman Sejati, Jakarta: Serambi, 2004

Lukito, Ratno, Hukum Islam dan Realitas Sosial, Yogyakarta: Cakrawala Media, 2008

Poerwadarminta, W.J.S., Kamus Umum Bahasa Indonesia, Jakarta: 1976

Qur'an Karim dan Terjemahan Artinya, UII Press, 2004

Rousseau,Jean Jacques, Du Contract Sosial (Perjanjian Sosial), terjemahan, Jakarta: Visimedia, 2007

Syafe'i, Rachmat, Ilmu Ushul Fiqh, Bandung, CV Pustaka Setia, 1998, Cet. IV

Syarifuddin, Amir, Ushul Fiqh, Cet I, Jilid II, Jakarta: Logos Wacana Ilmu, 1999

Syâtibi, Abû Ishâq al-, al-Muñâfaqât fi Usûul al-Syari`ah, juz I, Beirut: Dâr al-Kutub alIlmiyyah, t.th.,.

Taqiyah, M. Ibn Ahmad, Masadiru al Tasyri' al Islamy, Lebanon: Muasisu Al Kitab Al Tsaqofiyah, 1999

Zuhaili, Wahbah, Ilmu ushl Al Figh., juz II. 